Article

\title{
Visible-Light-Responsive Antibacterial Property of Boron-Doped Titania Films
}

\author{
Ming-Show Wong ${ }^{1}$, Man-Ting Sun ${ }^{1}$, Der-Shan Sun ${ }^{2}$ and Hsin-Hou Chang ${ }^{2, *(1)}$ \\ 1 Department of Materials Science and Engineering, National Dong Hwa University, Hualien 974, Taiwan; \\ mswong@gms.ndhu.edu.tw (M.-S.W.); 410122049@gms.ndhu.edu.tw (M.-T.S.) \\ 2 Department of Molecular Biology and Human Genetics, Tzu Chi University, Hualien 970, Taiwan; \\ dssun@mail.tcu.edu.tw \\ * Correspondence: hhchang@mail.tcu.edu.tw; Tel.: +886-3856-5301 (ext. 2667)
}

Received: 22 October 2020; Accepted: 17 November 2020; Published: 19 November 2020

\begin{abstract}
Pure titanium dioxide $\mathrm{TiO}_{2}$ photocatalytic substrates exhibit antibacterial activity only when they are irradiated with ultraviolet light, which comprises high-energy wavelengths that damage all life. Impurity doping of $\mathrm{TiO}_{2}$-related materials enables visible light to stimulate photocatalytic activity, which enhances opportunities for $\mathrm{TiO}_{2}$ to be used as a disinfectant in living environments. Boron-doped $\mathrm{TiO}_{2}$ displays visible-light-responsive bactericidal properties. However, because boron-derived compounds also exert notable antibacterial effects, most reports did not clearly demonstrate the extent to which the bactericidal property of boron-doped $\mathrm{TiO}_{2}$ is contributed by visible-light-stimulated photocatalysis. In addition, $\mathrm{TiO}_{2}$ thin films have considerable potential for applications in equipment that requires sterilization; however, the antibacterial properties of boron-doped $\mathrm{TiO}_{2}$ thin films have been examined by only a few studies. We found that boron-doped $\mathrm{TiO}_{2}$ thin films displayed visible-light-driven antibacterial properties. Moreover, because boron compounds may have intrinsic antibacterial properties, using control groups maintained in the dark, we clearly demonstrated that visible light stimulated the photocatalysis of boron-doped $\mathrm{TiO}_{2}$ thin films but not the residue boron compounds display antibacterial property. The bactericidal effects induced by visible light are equally potent for the elimination of the model organism Escherichia coli and human pathogens, such as Acinetobacter baumannii, Staphylococcus aureus, and Streptococcus pyogenes. The antibacterial applications of boron-doped $\mathrm{TiO}_{2}$ thin films are described, and relevant perspectives discussed.
\end{abstract}

Keywords: titanium dioxide $\mathrm{TiO}_{2}$; boron-doped $\mathrm{TiO}_{2}$; visible light responsive photocatalyst; antibacterial material

\section{Introduction}

Disinfectants are critical in the elimination of environmental pathogens for adequately maintaining a clean water supply, sanitation and hygiene services, and hospital facilities [1]. Titanium dioxide $\left(\mathrm{TiO}_{2}\right)$ materials are one of the most common photocatalysts used for antimicrobial applications [2]. The exposure of photocatalytic materials to ultraviolet (UV) light results in the generation of electron-hole pairs because electrons from the valence band are stimulated to enter the conduction band. Efficient photocatalysis utilizes these holes and electrons in reaction rather than in recombination, which is a process that involves the release of energy in the form of heat to cause incomplete photocatalysis. In efficient photocatalysis, antimicrobial reactive oxygen species are produced by reactions between excited electron-hole pairs and atmospheric water or oxygen [3]. However, the toxic effects of UV light prohibit the usage of UV photocatalysts in workplaces and living environments. The impurity doping of $\mathrm{TiO}_{2}$-related materials with various metal and nonmetal elements, which results 
in a shift of excitation wavelength from the UV region to the visible light, can be a feasible solution to this problem [2,4-13]. In addition, the recombination rates of electron-hole pairs can be reduced through the impurity doping of $\mathrm{TiO}_{2}$.

Research has revealed visible-light-induced antibacterial properties in boron-doped $\mathrm{TiO}_{2}$ [14-16]. However, in a previous study, boron-doped $\mathrm{TiO}_{2}$ was also found to exert a strong bactericidal effect in the dark [16]. Other evidence has revealed that without $\mathrm{TiO}_{2}$, boron-derived compounds exert levels of antibacterial properties [17-23]. As boron-containing materials display strong antibacterial properties, whether or how strongly the photocatalytic property contributes to the antibacterial property of boron-doped $\mathrm{TiO}_{2}$ requires further characterization. In addition, the antibacterial property of $\mathrm{TiO}_{2}$ thin films, which are a type of nanomaterial used largely in personal hygiene and clinical equipment [24], have been examined to a limited extent on the boron-doped films. Therefore, in the present study, we investigated the antibacterial property of boron-doped $\mathrm{TiO}_{2}$ thin films. Relevant implications and applications of this property are also discussed.

\section{Results}

\subsection{Analyses of Boron-Doped Titania Thin Films}

Following previously described methods [25], two series (as-deposited and annealed) of boron-doped $\mathrm{TiO}_{2}\left[\mathrm{TiO}_{2}(\mathrm{~B})\right]$ films with thickness ranging from $117 \mathrm{~nm}$ to $484 \mathrm{~nm}$ were prepared in this study. The as-deposited films were prepared under the same processing parameters by varying the deposition time and the annealed films were heat-treated at $600{ }^{\circ} \mathrm{C}$ in air for one hour. Field-emission scanning electron microscopy showed that the surfaces of the as-deposited $\mathrm{TiO}_{2}(\mathrm{~B})$ thin films were evenly coated with materials before and after annealing, nano-sized grains mixed with pores developed forming nanoporous films (Figure 1; experiment settings, Figure S1).
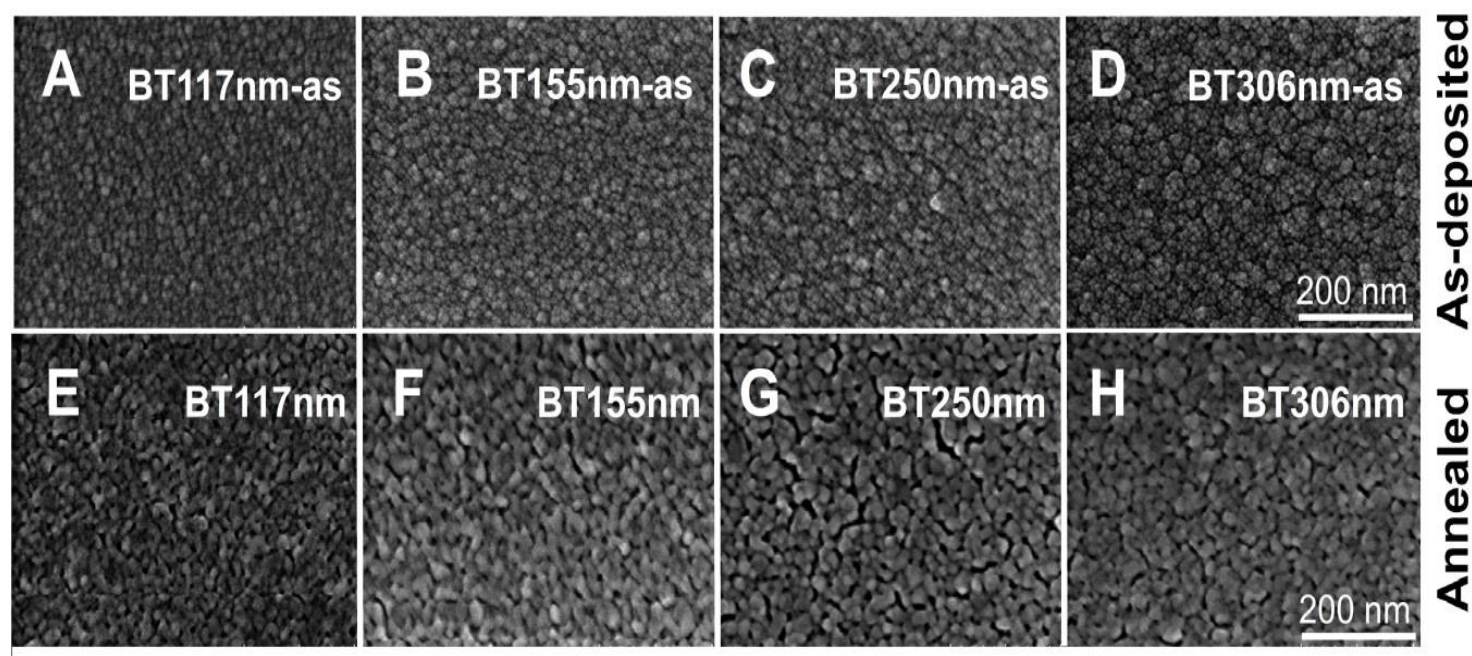

Figure 1. Field-emission scanning electron microscopy of $\mathrm{TiO}_{2}(\mathrm{~B})$ films. Examples of the vertical views $(\mathbf{A}-\mathbf{H})$ of $\mathrm{TiO}_{2}$ (B) films with various thickness, before (A-D) and after (E-H) annealing.

X-ray photoelectron spectroscopy (XPS) analysis indicated the deposition of boron in the films (Figure 2A,B; Table S1). The X-ray diffraction (XRD) results indicated that the anatase phase of titania was formed after the annealing (Figure 2C vs. Figure 2D) of the films. Absorption spectroscopy analysis in the ultraviolet-visible (UV-Vis) range revealed that no marked changes occurred after annealing, whereas the B-containing samples exhibited a marginal red shift, which indicated increased absorption in the visible light range (Figure 3A,B). 

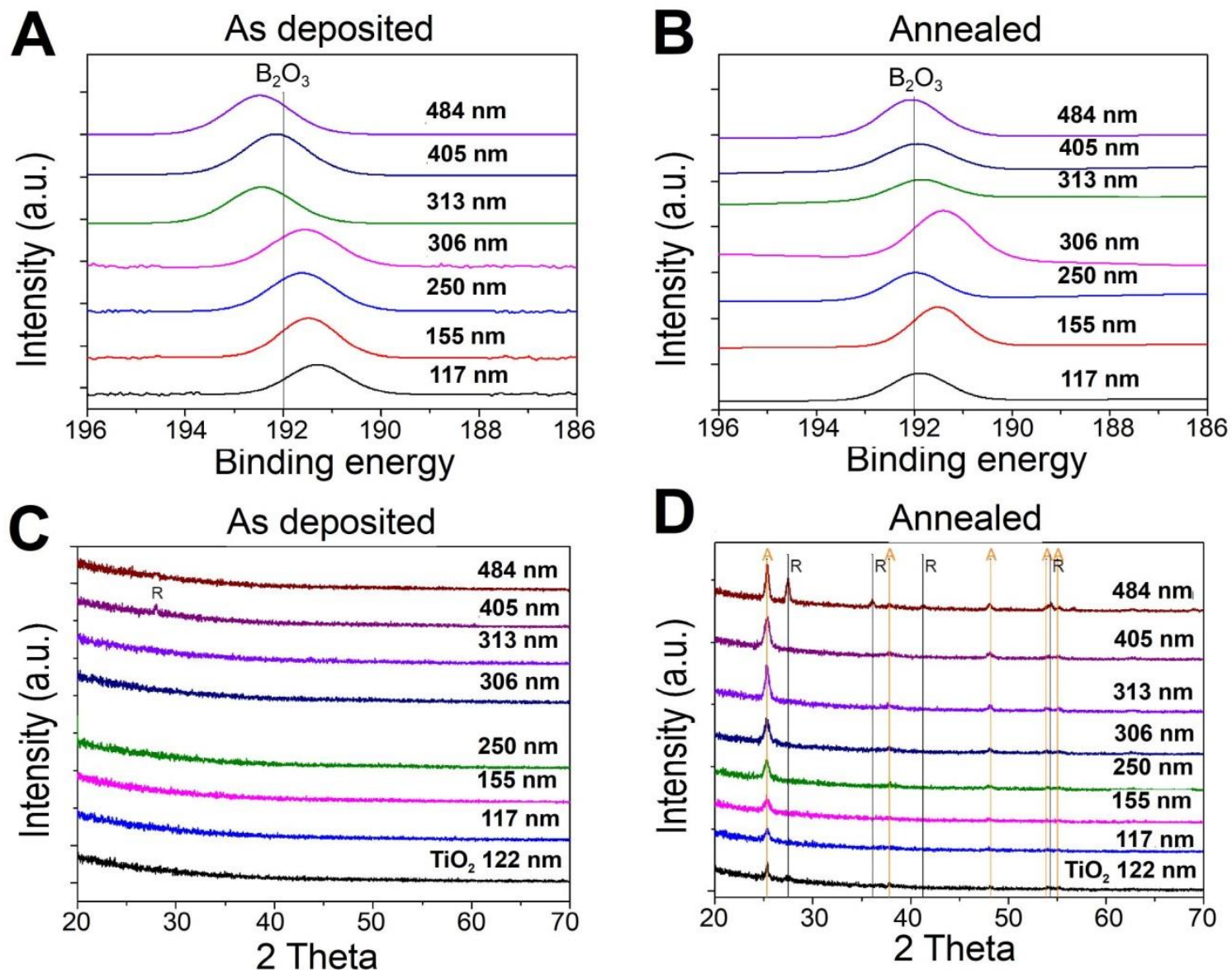

Figure 2. Boron contents in various $\mathrm{TiO}_{2}$ (B) films. The XPS results of surface composition of the $\mathrm{TiO}_{2}$ (B) films, ranging from $117 \mathrm{~nm}$ to $484 \mathrm{~nm}$, before (A) and after (B) annealing. X-day diffraction analysis results obtained before $(\mathbf{C})$ and after $(\mathbf{D})$ annealing. $\mathrm{TiO}_{2} 122 \mathrm{~nm}$ are control groups with pure $\mathrm{TiO}_{2}(\mathbf{C}, \mathbf{D})$.
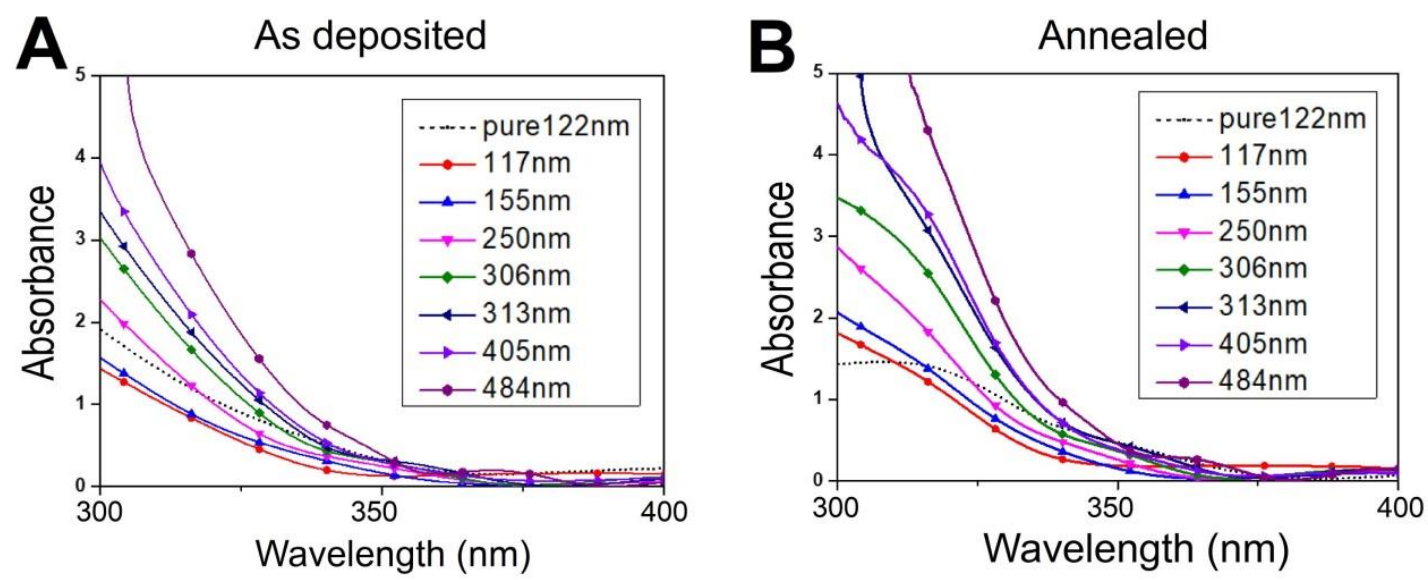

Figure 3. Ultraviolet (UV)-visible absorption spectroscopy analysis of $\mathrm{TiO}_{2}(\mathrm{~B})$ thin-film samples. The UV-visible absorption spectroscopy results of the $\mathrm{TiO}_{2}$ (B) films, ranging from $117 \mathrm{~nm}$ to $484 \mathrm{~nm}$, before (A) and after (B) annealing are showed.

Since the as-deposited films are prepared under the same conditions except for deposition time, their chemical composition is expected to be comparable. However, after annealing at $600{ }^{\circ} \mathrm{C}$ in air for one hour, some of the boron content may form $\mathrm{B}_{2} \mathrm{O}_{3}$ and evaporate away, leaving nanoporous $\mathrm{TiO}_{2}(\mathrm{~B})$ 
films with less boron content. The remaining boron in the $\mathrm{TiO}_{2}(\mathrm{~B})$ may exist as residual $\mathrm{B}_{2} \mathrm{O}_{3}$ and as $\left[\mathrm{BO}_{3}\right]$ and $\left[\mathrm{Ti}_{2} \mathrm{BO}_{2}\right]$ species in the $\mathrm{TiO}_{2}$ lattice and their effect on the XPS spectra and on UV-Vis spectra have been studied and discussed in our previous paper [25]. The amount and ratio of these boron related species in the annealed films are different due to film thickness. In addition to these data, the photocatalytic activity and antimicrobial property of $\mathrm{TiO}_{2}(\mathrm{~B})$ thin films require further investigation.

\subsection{Photocatalytic Activity and Escherichia Coli Killing Property of $\mathrm{TiO}_{2}(B)$ Thin Films}

The UV-driven and visible-light-driven photocatalytic properties were further investigated using a methylene blue (MB) degradation experiment. We found that $\mathrm{B}$ doping considerably increased the UV-induced and visible-light-induced photocatalytic responses, specifically in relatively thick $\mathrm{TiO}_{2}(\mathrm{~B})$ samples (Figure 4A,B). The degradation rate constant was also determined, with the $484 \mathrm{~nm}$ samples exhibiting the strongest catalytic property under visible light (Figure $4 \mathrm{C}$ ). In literature, crystalline anatase is the most active form for photocatalysis under UV light, but less effective under visible light, while mixed phases of anatase and rutile have a better photocatalytic performance under visible light $[5,26,27]$. This is consistent with the correlation between the phases of films in Figure 2D and the photocatalytic performance presented in Figure 4.
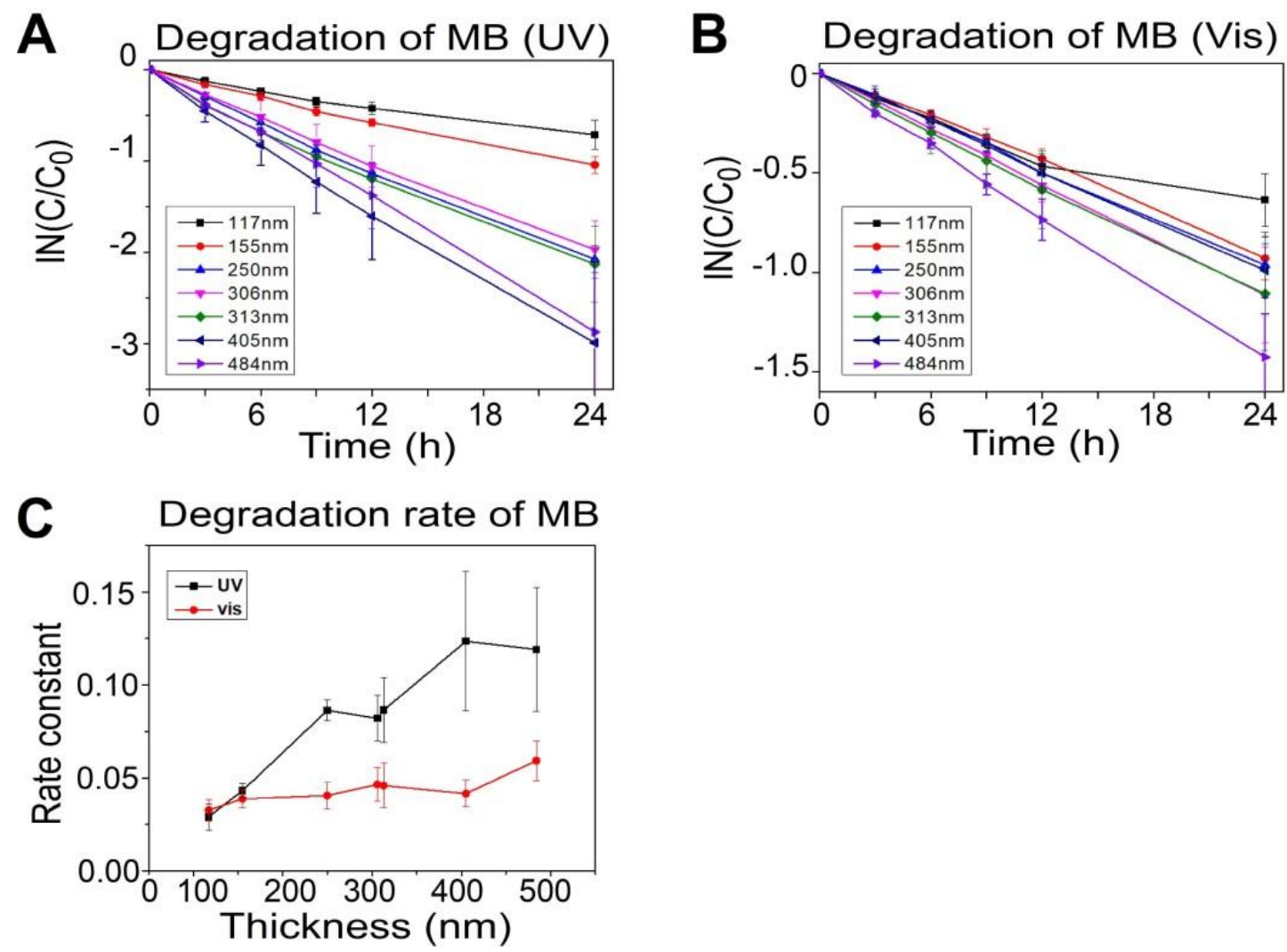

Figure 4. Methylene blue (MB) degradation analyses. The $\mathrm{MB}$ degradation of various $\mathrm{TiO}_{2}(\mathrm{~B})$ films, ranging from $117 \mathrm{~nm}$ to $484 \mathrm{~nm}$, under UV light (A), MB degradation of various $\mathrm{TiO}_{2}$ (B) films under visible light (B), and the degradation rate constant (C).

To investigate the antibacterial property of $\mathrm{TiO}_{2}(\mathrm{~B})$ thin films, the most commonly used bacterial model organism, Escherichia coli, was employed. Using the plating method, we found that, in agreement with $\mathrm{MB}$ degradation analysis, the $484 \mathrm{~nm} \mathrm{TiO}_{2}(\mathrm{~B})$ thin-film samples displayed the greatest bacteria-killing property under visible light illumination but not in the dark (Figure 5), which suggested the induction of antibacterial property by visible light. 


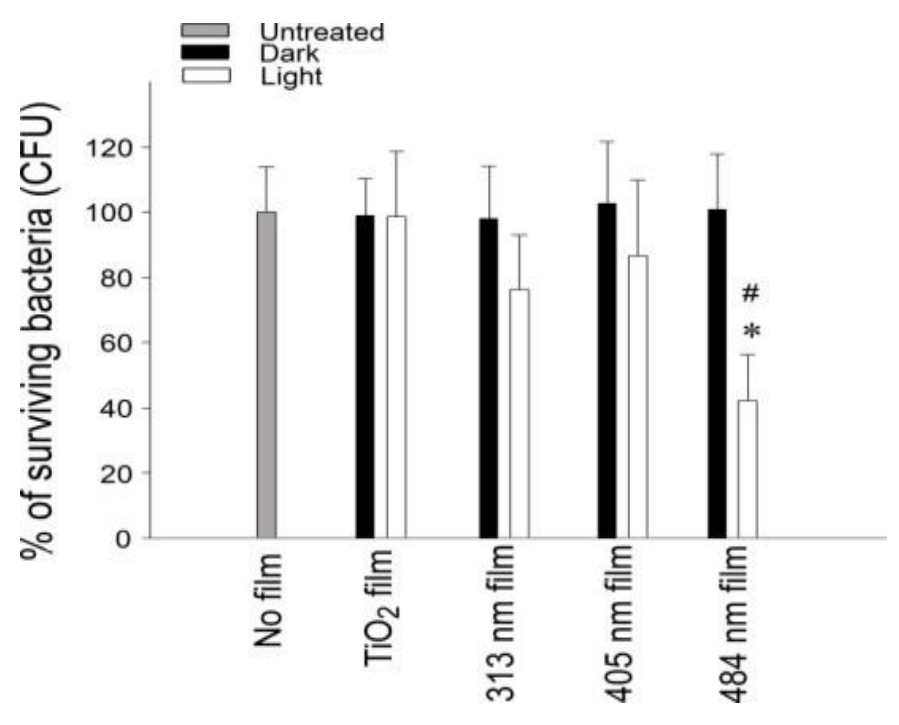

Figure 5. Visible-light-induced photolytic killing of Escherichia coli with or without treatments on various $\mathrm{TiO}_{2}$ substrates. Pure $\mathrm{TiO}_{2}$ films as well as 313, 405, and $484 \mathrm{~nm} \mathrm{TiO}$ (B) thin films were used. The percentage of surviving bacteria without placement on the films (no film, untreated groups) was normalized to $100 \%$. $\mathrm{n}=6, \# p<0.05$ (compared with the respective untreated group); ${ }^{*} p<0.05$ (compared with the respective dark group).

\subsection{Pathogen-Killing Property of $\mathrm{TiO}_{2}(B)$ Thin Films}

To investigate the performance of $\mathrm{TiO}_{2}$ (B) films in the eradication of pathogenic bacteria, Acinetobacter baumannii, Staphylococcus aureus, and Streptococcus pyogenes were used. A. baumannii and S. aureus are nosocomial infectious bacteria, which increase infections and mortality in hospitals [28]. We found that these three pathogens were markedly suppressed after the treatment of $\mathrm{TiO}_{2}$ (B) films with visible light with a wavelength of $484 \mathrm{~nm}$ (Figure 6, dark vs. light groups). The $\mathrm{TiO}_{2}$ (B) films displayed approximately equally potent bactericidal effects for the elimination of Gram-negative bacteria (A. baumannii) and Gram-positive bacteria (S. aureus and S. pyogenes) (Figure 6).

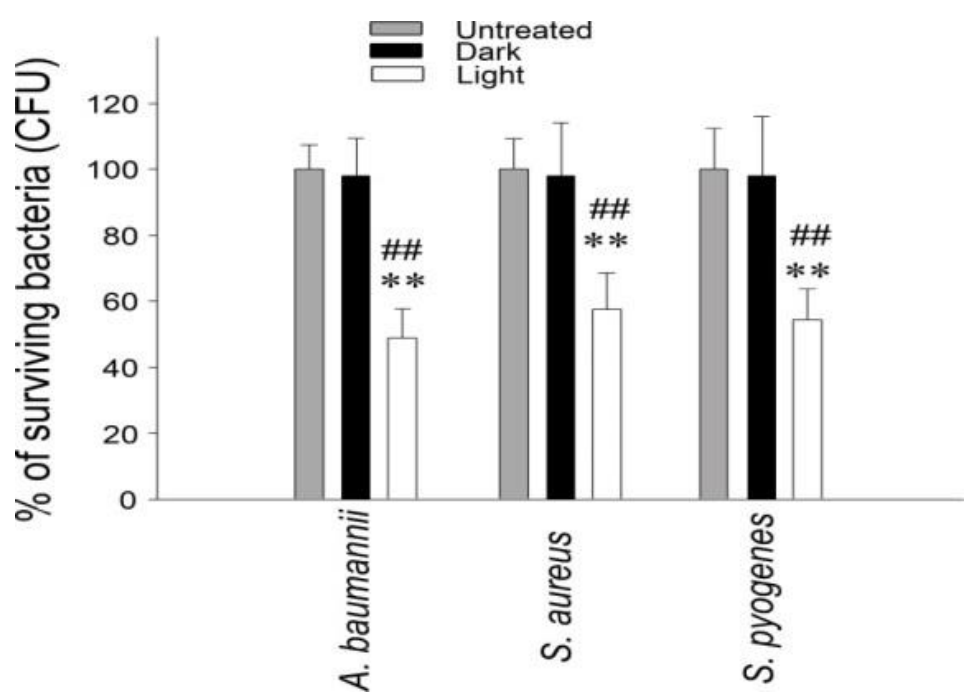

Figure 6. Visible-light-induced photolytic killing of pathogenic bacteria. The percentage of surviving bacteria without placement on the 484-nm $\mathrm{TiO}_{2}$ (B) film (untreated groups) was normalized to $100 \%$. $\mathrm{n}=6$, \#\# $p<0.01$ (compared with the respective untreated group), ${ }^{* *} p<0.01$ (compared with the respective dark group). 


\section{Discussion}

Various nanomaterials with antimicrobial properties have been developed [29] to reduce pathogenic microorganisms for the purposes of personal hygiene, water treatment, food production, and hospital facilities [1] and for controlling the spreading of infectious diseases during large epidemics [30]. The photocatalytic disinfection of bacteria by using various nanomaterials is a promising research area [31]. UV-stimulated $\mathrm{TiO}_{2}$ substrates are the most commonly used photocatalyst for antimicrobial purposes [2]. Because UV irradiation is harmful to humans, impurity doping in $\mathrm{TiO}_{2}$ with metal and nonmetal elements results in red shift of the excitation wavelength from UV to visible light [4-7]. This finding suggests that visible-light-driven photocatalysis may be a more feasible approach for killing bacteria than UV-driven photocatalysis is $[2,12,13]$. Despite the aforementioned findings, the visible-light-responsive antimicrobial property of nanoscale $\mathrm{TiO}_{2}(\mathrm{~B})$ films still requires further investigation.

Nanoscale thin films, which are low-dimension materials fabricated with a thickness in the nanometer range, are deposited onto substrate surfaces to achieve superior properties. The fabrication and characterization of thin films have a long history, with one early report describing thin-metal-film-deposited glassware [32]. Nanoscale thin films can theoretically be synthesized from a wide variety of materials, which opens the possibility of applications in various fields. For example, nanoscale thin films are primarily developed for physical, chemical, and electronic applications [33] and have also been used in biomedical applications [34]. Because visible-light-responsive antibacterial $\mathrm{TiO}_{2}$ (B) thin films have not yet been well characterized, in the present study, we characterized $\mathrm{TiO}_{2}(\mathrm{~B})$ thin films and found that they exhibited a visible-light-responsive photocatalytic property. Because the thickness of the $\mathrm{TiO}_{2}(\mathrm{~B})$ thin films determines the photocatalytic outcome, sufficient thickness is suggested to be crucial for visible-light-initiated photocatalysis.

Because boron-derived compounds exhibit levels of antibacterial properties [17-23], we investigated whether $\mathrm{TiO}_{2}$ (B) thin films also exerted an antibacterial effect in the dark. Analysis data from antibacterial experiments revealed that $\mathrm{TiO}_{2}(\mathrm{~B})$ thin films displayed no antibacterial effect in the dark, which suggested that no boron-derived nonphotocatalytic antibacterial property was involved in this system. In addition, the analysis results revealed that the antibacterial property of $\mathrm{TiO}_{2}$ (B) thin films reduced the live cell population of not only the model organism $E$. coli but also the human pathogenic bacteria A. baumannii, S. aureus, and S. pyogenes. The aforementioned results suggest that without the nonphotocatalytic antibacterial property of boron, $\mathrm{TiO}_{2}(\mathrm{~B})$ thin films continue to exhibit a visible-light-driven bactericidal effect. In addition, visible-light-responsive antibacterial $\mathrm{TiO}_{2}(\mathrm{~B})$ thin films may be a feasible material for the elimination of human pathogens.

\section{Materials and Methods}

\subsection{Preparation of $\mathrm{TiO}_{2}(B)$ Films}

$\mathrm{TiO}_{2}(\mathrm{~B})$ films were prepared using a reactive magnetron sputtering system (AJA International, Scituate, MA, USA) according to the methods described in [25]. The distance between the substrate holder and the targets was set as $100 \mathrm{~mm}$. The chamber was evacuated with an Alcatel mechanical pump and a turbomolecular pump (models 2015SD and TMU261; Pfeiffer Vacuum, de Brogny, France). The basal pressure was $4.0 \times 10^{-5} \mathrm{~Pa}$ or lower. Through sputtering from $99.99 \%$ titanium metal targets, $\mathrm{TiO}_{2}$ films were deposited at the substrate temperature of $100{ }^{\circ} \mathrm{C}$ with a constant power of $200 \mathrm{~W}$ for each $99.99 \%$ titanium metal target as well as one $99.5 \% \mathrm{TiB}_{2}$ target of $120 \mathrm{~W}$ in $\mathrm{Ar} / \mathrm{O}_{2}$ plasma. The gas flow rate was adjusted to be $20 \mathrm{sccm}$ for $\mathrm{Ar}$ and $8 \mathrm{sccm}$ for $\mathrm{O}_{2}$ under a total pressure of approximately $4.0 \times 10^{-1} \mathrm{~Pa}\left(3.0 \times 10^{-3}\right.$ Torr $)$. A series of films with thickness ranging from $117 \mathrm{~nm}$ to $484 \mathrm{~nm}$ was prepared by controlling the deposition time. Polished Si (100) wafers and glass and fused quartz slides were used as substrates. All the substrates were solvent-cleaned before use and sputter-etched with argon plasma for $10 \mathrm{~min}$ prior to the film deposition to remove potential pollutants on the surfaces. 


\subsection{Characterization of $\mathrm{TiO}_{2}(B)$ Films}

On the basis of the methods described in $[8,25]$, the structure and crystallinity of $\mathrm{TiO}_{2}(\mathrm{~B})$ films were analyzed using XRD measurements recorded using an X-ray diffractometer (D/MAX-2500V, Rigaku, The Woodlands, TX, USA) with a $\mathrm{Cu} \mathrm{K} \alpha$ radiation $(40 \mathrm{kV}, 100 \mathrm{~mA})$ source. The surface morphology and cross-section view of the films was observed using field-emission scanning electron microscopy (SEM; JEM-6500F, JEOL, Tokyo, Japan). The thickness of the films was measured using a surface profilometer (DektakXT, Bruker, Germany) and double-checked with SEM cross-sectional view. The UV-Vis absorption spectra of the films were recorded using a spectrophotometer (JASCO V-650) with a wavelength range of 300-900 nm. The composition of samples was determined through energy-dispersive spectroscopy (EMAX-ENERGY, Horiba, Kyoto, Japan) and X-ray photoelectron spectroscopy (K-Alpha, Thermo Fisher Scientific, Waltham, MA, USA) by using an AlK $\alpha$ X-ray radiation source to estimate elements semi-quantitatively.

\subsection{Photocatalytic Properties}

The analysis protocols were based on the methods reported in $[4,25,35,36]$, in which the MB (Sigma-Aldrich, St. Louis, MO, USA) degradation rate is used to analyze the photocatalytic performance of impurity-doped $\mathrm{TiO}_{2}$. By determining the degradation of $10 \mathrm{ppm} \mathrm{MB}$, the photocatalytic efficiency of the $\mathrm{TiO}_{2}$ (B) films was evaluated. For measurements with a UV-Vis spectrometer, the intensities of light absorption at $664 \mathrm{~nm}$ were used to determine the concentration of $\mathrm{MB}$ in tested solution. A sample of fixed size $(1 \mathrm{~cm} \times 1 \mathrm{~cm})$ was submerged in $2 \mathrm{~mL}$ of the MB-containing aqueous solution. An $8 \mathrm{~W}$ fluorescent lamp (UVItech-LF104L) with a wavelength distribution of 300-400 $\mathrm{nm}$ and a maximum intensity of $370 \mathrm{~nm}$ was used for UV irradiation. The distance between the UV light source and the sample was $10 \mathrm{~cm}$, which resulted in an average power intensity of $3.2 \mathrm{~mW} / \mathrm{cm}^{2}$ [25]. A fluorescent lamp (P-LF27W/865, Philips Taiwan, Taipei, Taiwan) with a wavelength distribution of approximately $400-750 \mathrm{~nm}$ and a maximum intensity of $543-611 \mathrm{~nm}$ was used to perform visible light illumination as described in [8]. With $8 \mathrm{~cm}$ between the visible light source and the samples, the lamp produced an average power density of $4.2 \mathrm{~mW} / \mathrm{cm}^{2}$.

\subsection{Antibacterial Experiment}

Standard protocols for bacterial culture, plating, and storage and for determining bacterial counts were performed in accordance with the methods described in [5,8,37-39]. For example, the bacterial counts were determined using the standard plating method or optical density readings at $595 \mathrm{~nm}\left(\mathrm{OD}_{595}\right)$. The conversion factor for $E$. coli was calculated to be $1 \times 10^{9}$ colony-forming units (CFUs)/mL at $\mathrm{OD}_{595}$, and the cultures were diluted with the culture medium to $1 \times 10^{7} \mathrm{CFUs} / \mathrm{mL}$ [8]. For the photocatalytic killing of bacterial cells, the $1 \times 10^{6} \mathrm{CFU}$ culture was dripped onto the sample (bacterial-containing droplet covered area with approximately $6.25 \mathrm{~cm}^{2}$ ) and was then placed in a dark room or exposed to visible light at room temperature. An incandescent lamp (Classictone incandescent lamp, $60 \mathrm{~W}$, Philips; Taipei, Taiwan) was used as the visible light source. The illumination density was recorded using a light meter (model LX-102; Lutron Electronic Enterprises, Taipei, Taiwan) [8]. The illumination distance between the sample and the lamp was approximately $10 \mathrm{~cm}$, with exposure lasting for $30 \mathrm{~min}$. Moreover, the light intensity on the sample surface was almost $1.2 \times 10^{3}$ lux (lumen/m $\left.\mathrm{m}^{2}\right)\left(30 \mathrm{~mW} / \mathrm{cm}^{2}\right)$ in the photocatalytic reaction. After illumination, $100 \mu \mathrm{L}$ of the bacterial solution was recovered from the photocatalytic substrates. Finally, standard dilution and plating methods were used to determine the live bacterial levels [8]. Clinical isolates of S. aureus (strain SA02), pandrug-resistant A. baumannii (strain M36788), and S. pyogenes (strain M29588) were provided by the Buddhist Tzu-Chi General Hospital in Hualien, Taiwan [5,8]. LB agar (BD Diagnostics, Sparks, MD, USA) or lysogeny broth (LB) medium was used to maintain E. coli. Moreover, A. baumannii. S. pyogenes, and S. aureus were grown in tryptic soy broth with yeast extract (TSBY) or TSBY broth agar (MDBio, Inc., Taipei, Taiwan) at $37^{\circ} \mathrm{C}$. 
To prevent the illumination of small parts of the sample with UV wavelengths in the photocatalytic experiments, a UV cut-off filter (400 nm; Edmund Optics, Barrington, NJ, USA) was used [8].

\subsection{Statistical Analysis}

In this study, means, standard deviations, and all other statistics were calculated using Microsoft Office Excel 2003 and SigmaPlot 10 to obtain statistical and quantitative analysis data. A post hoc Bonferroni corrected test followed by one-way analysis of variance was performed to determine the significance of the data, and the probability of the type I error $(\alpha)$ being equal to or greater than 0.05 was recognized as statistically significant.

\section{Conclusions}

In the present study, $\mathrm{TiO}_{2}(\mathrm{~B})$ thin films exhibited a visible-light-driven degradation and bactericidal effects without the nonphotocatalytic antibacterial property of boron. In addition, the visible-light-responsive antibacterial $\mathrm{TiO}_{2}(\mathrm{~B})$ thin films proved to be feasible materials for the control and elimination of human pathogens. The as-deposited films are amorphous and after annealing at $600{ }^{\circ} \mathrm{C}$ in air for one hour, some of the boron content evaporated away, leaving nanoporous $\mathrm{TiO}_{2}(\mathrm{~B})$ films with less boron content. The photocatalytic effects are increasing with the film thickness in general, but the phase of the films also plays a significant role. The thicker $\mathrm{TiO}_{2}$ (B) film of mixed phases of anatase and rutile shows better photocatalytic performance under visible light.

Supplementary Materials: The following are available online at http://www.mdpi.com/2073-4344/10/11/1349/s1: Figure S1: Experimental settings and Table S1: X-ray photoelectron spectroscopy composition analysis.

Author Contributions: Conceptualization, M.-S.W. and H.-H.C.; investigation, M.-S.W., M.-T.S. and D.-S.S.; writing-original draft preparation, M.-S.W. and H.-H.C.; funding acquisition, H.-H.C. All authors have read and agreed to the published version of the manuscript.

Funding: This research was funded by the Ministry of Science and Technology, Taiwan, under the grant number 107-2311-B-320-002-MY3; Tzu-Chi University under the grant numbers TCIRP95002, TCIRP98001, and TCIRP101001; and Tzu-Chi Medical Foundation under the grant numbers TC-NHRI105-02, TCMMP104-06, TCMMP108-04, and TCAS-108-01.

Conflicts of Interest: The authors declare no conflict of interest.

\section{References}

1. McDonnell, G.; Russell, A.D. Antiseptics and disinfectants: Activity, action, and resistance. Clin. Microbiol. Rev. 1999, 12, 147-179. [CrossRef] [PubMed]

2. Liou, J.W.; Chang, H.H. Bactericidal effects and mechanisms of visible light-responsive titanium dioxide photocatalysts on pathogenic bacteria. Arch. Immunol. Ther. Exp. 2012, 60, 267-275. [CrossRef]

3. Linsebigler, A.L.; Lu, G.; Yates, J.T. Photocatalysis on $\mathrm{TiO}_{2}$ surfaces: Principles, mechanisms, and selected results. Chem. Rev. 1995, 95, 735-758. [CrossRef]

4. Asahi, R.; Morikawa, T.; Ohwaki, T.; Aoki, K.; Taga, Y. Visible-light photocatalysis in nitrogen-doped titanium oxides. Science 2001, 293, 269-271. [CrossRef] [PubMed]

5. Wong, M.S.; Chu, W.C.; Sun, D.S.; Huang, H.S.; Chen, J.H.; Tsai, P.J.; Lin, N.T.; Yu, M.S.; Hsu, S.F.; Wang, S.L.; et al. Visible-light-induced bactericidal activity of a nitrogen-doped titanium photocatalyst against human pathogens. Appl. Environ. Microbiol. 2006, 72, 6111-6116. [CrossRef] [PubMed]

6. Wong, M.S.; Sun, D.S.; Chang, H.H. Bactericidal performance of visible-light responsive titania photocatalyst with silver nanostructures. PLoS ONE 2010, 5, e10394. [CrossRef] [PubMed]

7. Yu, J.C.; Ho, W.; Yu, J.; Yip, H.; Wong, P.K.; Zhao, J. Efficient visible-light-induced photocatalytic disinfection on sulfur-doped nanocrystalline titania. Environ. Sci. Technol. 2005, 39, 1175-1179. [CrossRef]

8. Wong, M.S.; Chen, C.W.; Hsieh, C.C.; Hung, S.C.; Sun, D.S.; Chang, H.H. Antibacterial property of Ag nanoparticle-impregnated N-doped titania films under visible light. Sci. Rep. 2015, 5, 11978. [CrossRef]

9. Kau, J.H.; Sun, D.S.; Huang, H.H.; Wong, M.S.; Lin, H.C.; Chang, H.H. Role of visible light-activated photocatalyst on the reduction of anthrax spore-induced mortality in mice. PLoS ONE 2009, 4, e4167. [CrossRef] 
10. Tseng, Y.H.; Sun, D.S.; Wu, W.S.; Chan, H.; Syue, M.S.; Ho, H.C.; Chang, H.H. Antibacterial performance of nanoscaled visible-light responsive platinum-containing titania photocatalyst in vitro and in vivo. Biochim. Biophys. Acta 2013, 1830, 3787-3795. [CrossRef]

11. Liou, J.W.; Gu, M.H.; Chen, Y.K.; Chen, W.Y.; Chen, Y.C.; Tseng, Y.H.; Hung, Y.J.; Chang, H.H. Visible light responsive photocatalyst induces progressive and apical-terminus preferential damages on Escherichia coli surfaces. PLoS ONE 2011, 6, e19982. [CrossRef] [PubMed]

12. Sun, D.S.; Kau, J.H.; Huang, H.H.; Tseng, Y.H.; Wu, W.S.; Chang, H.H. Antibacterial Properties of Visible-Light-Responsive Carbon-Containing Titanium Dioxide Photocatalytic Nanoparticles against Anthrax. Nanomaterials 2016, 6, 237. [CrossRef] [PubMed]

13. Sun, D.S.; Tseng, Y.H.; Wu, W.S.; Wong, M.S.; Chang, H.H. Visible Light-Responsive Platinum-Containing Titania Nanoparticle-Mediated Photocatalysis Induces Nucleotide Insertion, Deletion and Substitution Mutations. Nanomaterials 2016, 7, 2. [CrossRef]

14. Sopchenskia, L.; Cogob, S.; Dias-Ntipanyjb, M.F.; Elifio-Espósitob, S.; Popatc, K.C.; Soaresa, P. Bioactive and antibacterial boron doped TiO2 coating obtained by PEO. Appl. Surf. Sci. 2018, 458, 49-58. [CrossRef]

15. Prasad, S.S.; Datta, S.; Adarsh, T.; Diwan, P.; Annapurna, K.; Kundu, B.; Biswas, K. Effect of boron oxide addition on structural, thermal, in vitro bioactivity and antibacterial properties of bioactive glasses in the base S53P4 composition. J. Non-Cryst. Solids 2018, 498, 204-215. [CrossRef]

16. Wang, Y.; Xue, X.; Yang, H. Synthesis and Antimicrobial Activity of Boron-doped Titania Nano-materials. Chin. J. Chem. Eng. 2014, 22, 474-479. [CrossRef]

17. Argin, S.; Gulerim, M.; Sahin, F. Development of antimicrobial gelatin films with boron derivatives. Turk. J. Biol. 2019, 43, 47-57. [CrossRef]

18. Kivanc, M.; Barutca, B.; Koparal, A.T.; Goncu, Y.; Bostanci, S.H.; Ay, N. Effects of hexagonal boron nitride nanoparticles on antimicrobial and antibiofilm activities, cell viability. Mater. Sci. Eng. C Mater. Biol. Appl. 2018, 91, 115-124. [CrossRef] [PubMed]

19. Frimannsson, D.O.; Grossi, M.; Murtagh, J.; Paradisi, F.; O'Shea, D.F. Light induced antimicrobial properties of a brominated boron difluoride $(\mathrm{BF}(2))$ chelated tetraarylazadipyrromethene photosensitizer. J. Med. Chem. 2010, 53, 7337-7343. [CrossRef] [PubMed]

20. Luan, Q.; Desta, T.; Chehab, L.; Sanders, V.J.; Plattner, J.; Graves, D.T. Inhibition of experimental periodontitis by a topical boron-based antimicrobial. J. Dent. Res. 2008, 87, 148-152. [CrossRef] [PubMed]

21. Alencar de Queiroz, A.A.; Abraham, G.A.; Pires Camillo, M.A.; Higa, O.Z.; Silva, G.S.; del Mar Fernandez, M.; San Roman, J. Physicochemical and antimicrobial properties of boron-complexed polyglycerol-chitosan dendrimers. J. Biomater. Sci. Polym. Ed. 2006, 17, 689-707. [CrossRef]

22. Kilic, A.; Beyazsakal, L.; Findik, B.T.; Incebay, H. Synthesis and electrochemical investigation of chiral amine bis(phenolate)-boron complexes: In vitro antibacterial activity screening of boron compounds. Inorg. Chim. Acta 2020, 510. [CrossRef]

23. Sayin, Z.; Ucan, U.S.; Sakmanoglu, A. Antibacterial and Antibiofilm Effects of Boron on Different Bacteria. Biol. Trace Elem. Res. 2016, 173, 241-246. [CrossRef] [PubMed]

24. Piedade, A.P.; Romeu, F.; Branco, R.; Morais, P.V. Thin Films for Medical and Environmental Applications. In Methods for Film Synthesis and Coating Procedures; IntechOpen: London, UK, 2018. [CrossRef]

25. Shen, S.J.; Yang, T.S.; Wong, M.S. Co-sputtered boron-doped titanium dioxide films as photocatalysts. Surf. Coat. Technol. 2016, 303, 184-190. [CrossRef]

26. Cheng, C.L.; Sun, D.S.; Chu, W.C.; Tseng, Y.H.; Ho, H.C.; Wang, J.B.; Chung, P.H.; Chen, J.H.; Tsai, P.J.; Lin, N.T.; et al. The effects of the bacterial interaction with visible-light responsive titania photocatalyst on the bactericidal performance. J. Biomed. Sci. 2009, 16, 7. [CrossRef]

27. Chen, Y.L.; Chen, Y.S.; Chan, H.; Tseng, Y.H.; Yang, S.R.; Tsai, H.Y.; Liu, H.Y.; Sun, D.S.; Chang, H.H. The use of nanoscale visible light-responsive photocatalyst TiO2-Pt for the elimination of soil-borne pathogens. PLoS ONE 2012, 7, e31212. [CrossRef]

28. Chen, Y.Y.; Chen, L.Y.; Lin, S.Y.; Chou, P.; Liao, S.Y.; Wang, F.D. Surveillance on secular trends of incidence and mortality for device-associated infection in the intensive care unit setting at a tertiary medical center in Taiwan, 2000-2008: A retrospective observational study. BMC Infect. Dis. 2012, 12, 209. [CrossRef]

29. Ogunsona, E.O.; Muthuraj, R.; Ojogbo, E.; Valerio, O.; Mekonnen, T.H. Engineered nanomaterials for antimicrobial applications: A review. Appl. Mater. Today 2020, 18, 100473. [CrossRef] 
30. Talebian, S.; Wallace, G.G.; Schroeder, A.; Stellacci, F.; Conde, J. Nanotechnology-based disinfectants and sensors for SARS-CoV-2. Nat. Nanotechnol. 2020, 15, 618-621. [CrossRef] [PubMed]

31. Wang, W.; Huang, G.; Yu, J.C.; Wong, P.K. Advances in photocatalytic disinfection of bacteria: Development of photocatalysts and mechanisms. J. Environ. Sci. 2015, 34, 232-247. [CrossRef]

32. Velu, R.; Calais, T.; Jayakumar, A.; Raspall, F. A Comprehensive Review on Bio-Nanomaterials for Medical Implants and Feasibility Studies on Fabrication of Such Implants by Additive Manufacturing Technique. Materials 2019, 13, 92. [CrossRef] [PubMed]

33. Van Zeijl, H.W. Thin Film Technologies for Micro/Nano Systems; A Review. ECS Trans. 2014, 61, $191-206$. [CrossRef]

34. De Falco, G.; Porta, A.; Petrone, A.M.; Del Gaudio, P.; El Hassanin, A.; Commodo, M.; Minutolo, P.; Squillace, A.; D'Anna, A. Antimicrobial activity of flame-synthesized nano- $\mathrm{TiO}_{2}$ coatings. Environ. Sci. Nano 2017, 4, 1095-1107. [CrossRef]

35. Lin, L.; Lin, W.; Zhu, Y.; Zhao, B.; Xie, Y.; He, Y.; Zhu, Y. Uniform carbon-covered titania and its photocatalytic property. J. Mol. Catal. A Chem. 2005, 236, 46-53. [CrossRef]

36. Zhang, H.; Zong, R.; Zhao, J.; Zhu, Y. Dramatic visible photocatalytic degradation performances due to synergetic effect of $\mathrm{TiO}_{2}$ with PANI. Environ. Sci. Technol. 2008, 42, 3803-3807. [CrossRef]

37. Chang, H.H.; Lo, S.J. Modification with a phosphorylation tag of PKA in the TraT-based display vector of Escherichia coli. J. Biotechnol. 2000, 78, 115-122. [CrossRef]

38. Chang, H.J.; Sheu, S.Y.; Lo, S.J. Expression of foreign antigens on the surface of Escherichia coli by fusion to the outer membrane protein traT. J. Biomed. Sci. 1999, 6, 64-70. [CrossRef] [PubMed]

39. Chang, H.H.; Shih, K.N.; Lo, S.J. Receptor-mediated endocytosis as a selection force to enrich bacteria expressing rhodostomin on their surface. J. Biomed. Sci. 2000, 7, 42-50. [CrossRef] [PubMed]

Publisher's Note: MDPI stays neutral with regard to jurisdictional claims in published maps and institutional affiliations. 